\title{
India and the European Union: A Quick Look at their Legal Relations and their Strategic Partnership
}

\author{
By Harry Stamelos ${ }^{*} \&$ Konstantinos Tsimaras ${ }^{*}$
}

\begin{abstract}
This short introductory overview of the bilateral relations between India and the EU purports to draw the attention of researchers regarding the framework of the legal relations and the Strategic Partnership of India and the EU, two of the most significant global players. In the Appendices the Cooperation Agreement of 1993/1994 and the Strategic Partnership of 2004 are copied to facilitate the full access to the relevant texts. This quick look at the framework of the relations between India and the EU obviously proves that in the next years their relations are expected to be even broader and their laws and policies shall be interrelated and affected both ways in a wide range of areas at various economic and social levels.
\end{abstract}

Keywords: India-EU bilateral relations; India-EU Cooperation Agreement; India-EU Strategic Partnership.

\section{Introduction}

In 2017, India and the European Union celebrated fifty-five years of bilateral relations. Since 1962, India and the European Union ('EU') relations have been deeply changed, including commerce, policies regarding safety and security, transport, environmental issues, climate change, energy, education, research and innovation, as well as contacts of their citizens.

The Cooperation Agreement between India and the EU concluded in 1993/ 1994 (see Appendix A) sets the basis for the bilateral relations of these two important legal orders. Indeed, regular summits between the two parties have improved the India-EU cooperation in all fields since 2000 leading to the Strategic Partnership of 2004 (see Appendix B).

\footnotetext{
*LL.B., LL.M. (EU law), LL.M. (History of the Law), Ph.D. (Law). Scientific Collaborator, School of Law, European University Cyprus, Engomi, Nicosia, Cyprus. E-mail: charalamposstamelos@gmail.com.

${ }^{\ddagger}$ LL.B., LL.M. (Public Law), M.A. (Political Science), Ph.D. (Law), Associate Professor, Dean. School of Law, European University Cyprus, Engomi, Nicosia, Cyprus. E-mail:

k.tsimaras@euc.ac.cy.
} 


\section{Areas of Cooperation between India and the EU}

In early October 2017 the fourteenth India-EU Summit took place in the capital of India. That Summit issued a Joint Statement and three joint declarations added to the previous year Summit adopted the India-EU Agenda for Action 2020.

The first joint declaration of India and the EU was on counter-terrorism. Terrorism is a significant threat nowadays in an era of global instability and violations of the laws ${ }^{1}$.

The second joint declaration of India and the EU was on clean energy and on climate change ${ }^{2}$. Even Donald Trump, the President of the United States of America, recognised the fact that climate change is a global problem by hiring a University Professor as his personal advisor on this matter ${ }^{3}$. Technology and industries improve daily life, but simultaneously they establish circumstances under which pollution significantly alter the natural environment which causes climate change.

The third joint of India and the EU was on a partnership for smart and sustainable urbanisation. For the first time in human history, in 2018 half of the population of the planet now resides in cities making the living standards and conditions harder to cope with. Sustainable urbanisation will be one the biggest problems in the future given the fact that more people abandon a farmland to start their lives in the promising metropolis hoping to pursue happiness in an artificial environment.

Regular parliamentary exchanges help to promote understanding and deepen the India-EU partnership. In February 2017 a visit of three different committees from the European Parliament to India took place and in spring 2018 the Indian Parliament re-established the India-European Union Parliamentary Friendship Group ${ }^{4}$.

\section{Foreign Policy and Security}

In the sector of foreign policy and security cooperation, India and the EU discuss such matters in a number of fora and at various levels, including at the Summits. Regular ministerial-level meetings help to move forward the implementation of the Summit conclusions and steer the cooperation.

\footnotetext{
${ }^{1}$ Zahid (2017): 'Perhaps no other country is as diverse as the Indian society, having a plethora of ethnic, communal, religious and sectarian groups including some who have indeed resorted to violence because of a wide range of issues. Considering the demographics of India, a highly diverse society divided on religious, communal, caste, sectarian, and ethnic lines, the majoritarianism policy of BJP would likely to be a blowback for the Indian State. As prominent terrorism scholar Jessica Stern has pointed out, the major root causes of terrorism are humiliations, alienation and revenge. Hence, it could be projected that the growing alienation coupled with humiliation of minority groups may bring waves of communal violence'. See also NDTV (2018).

${ }^{2}$ Rattani (2017).

${ }^{3}$ Lavelle (2018).

${ }^{4}$ European Union External Action (2018).
} 
Regular foreign policy and security consultations represent a useful platform to exchange views on the full spectrum of bilateral, regional and global foreign policy issues. Security dialogues or consultations are regularly held on counterterrorism, counter-piracy, cyber-security, and non-proliferation/ disarmament ${ }^{5}$.

\section{Commerce}

In the field of commerce, it must be noted that India's largest trading partner is the European Union ${ }^{6}$. India is the EU's ninth largest ${ }^{7}$ partner. Bilateral trade in commercial services has almost tripled over the past decade. Overall, the EU is the second largest investor in India ${ }^{8}$.

Given the potential in India-EU trade, the two parties have been negotiating a Free Trade Agreement since 2007, covering, inter alia, effective market access in goods, services and public procurement, as well as a framework for investment including investment protection and rules that frame trade, such as intellectual property and competition. In 2013 the negotiations were put on hold as there was not sufficient progress on key outstanding issues that include improved market access for some goods and services, government procurement, geographical indications, sound investment protection rules and sustainable development. Since the India-EU Summit in October 2017, both sides have engaged actively in technical discussions on key issues in order to assess whether to relaunch the negotiations.

\section{Agriculture, Environment, Climate Change, and Energy}

Besides, India and the EU share a number of interests across a range of policy areas, including, as aforementioned, energy and climate change; environment. This is reflected in the breadth and depth of India-EU bilateral contacts, which take place in a number of fora and at various levels, including decentralised cooperation between EU and Indian cities. Policy cooperation and dialogue

\footnotetext{
${ }^{5}$ To support these, a series of events are held, for example a Workshop on Countering Online Radicalisation in May 2018 to exchange best practices. European Union External Action (2018).

${ }^{6}$ Accounting for $13.2 \%$ of India's overall trade, ahead of China $(11.6 \%)$ and the United States $(9.6 \%)$.

${ }^{7}$ The value of EU exports of goods to India amounting to $€ 41.7$ billion in 2017 . The total value of India-EU trade in goods stood at $€ 85.8$ billion in 2017. Major EU exports to India include engineering goods $(37 \%)$, gems and jewellery (16.8\%) and chemical and allied products $(10.4 \%)$. The primary EU imports include textiles and clothing (17.8\%), chemical and allied products $(14.1 \%)$ and engineering goods $(15.2 \%)$.

${ }^{8}$ With $€ 70$ billion of cumulative FDI from April 2000 to March 2017, accounting for almost one-quarter of all investments flows into India. The EU is also key destination for Indian foreign investments. The EU was the third largest recipient (€3.2 billion) of Indian FDIs, after Singapore and Mauritius, in 2016-17.
} 
between India and EU in these areas are further enriched and translated into operational cooperation with the help of EU's Partnership Instrument.

As regards environment, article 17 of the 1994 India-EC Cooperation Agreement provides for the following:

'1. The Contracting Parties recognize the need to take account of environmental protection as an integral part of economic and development cooperation. Moreover, they underline the importance of environmental issues and their will to establish cooperation in protecting and improving the environment with particular emphasis on water, soil and air pollution, erosion, deforestation and sustainable management of natural resources, taking into account the work done in international fora.

Particular attention will be paid to:

(a) the sustainable management of forest eco-systems;

(b) protection and conservation of natural forests;

(c) the strengthening of forestry institutes;

(d) the finding of practical solutions to rural energy problems;

(e) prevention of industrial pollution;

(f) protection of the urban environment.

2. Cooperation in this area will centre on:

(a) reinforcing and improving environmental protection institutions;

(b) developing legislation and upgrading standards;

(c) research, training and information;

(d) executing studies and pilot programmes and providing technical assistance.'

Both parties realise that the problems relating to the environment are global and the solutions of such problems should be the outcome of an extensive cooperation both at the bilateral and the multilateral levels. Thus, the EU and India accept the work done in international fora. Moreover, the prevention of industrial pollution draws the particular attention of EU and India. Industrial pollution is one of the most significant problems relating to the environment and its protection. Although it is now very difficult to forecast the exact steps of the next ten years, the fact that both the EU and India pay particular attention to the prevention of industrial pollution is extremely important. More specific, this problem can only be dealt with the necessary cooperation and the clean energy projects should affect in a positive way the attempts of the contracting parties to eliminate the industrial pollution for the benefit of all citizens of both contracting parties. To live in a healthy environment would foster a healthy economic growth. This is why the parties agree to cooperate in research, training and information, in order to encourage more natural and legal persons to develop new ideas for industries to consume clean energy. Of course, all such measures should be based on updated and new legislation. Legislators of both parties shall take into account the new 
trends to provide for improved solutions for the protection of the environment and to establish clean energy not only for the industries but for all consumers. In this framework, the protection and conservation of natural forests is crucial, as global warming leads to more fires in the forests causing enormous disasters in the eco systems of forests. The EU and India are well aware of all the important issues regarding the environment and its protection and they are willing to establish a permanent cooperation between them to deal with all these problems in an effective way.

India and the EU remain close partners in the G20 context and have developed a regular macroeconomic dialogue to exchange experience on economic policies and structural reforms ${ }^{9}$. India has rapidly growing energy needs due to a growing GDP and population and a huge energy infrastructure deficit. India is focussing on domestic production, including renewables and nuclear, and on energy efficiency. India-EU energy cooperation was considerably strengthened over the past years, which led to the launch of an India-EU Clean Energy and Climate Partnership. The partnership brings together, in a joined-up approach, the EU and its Member States, EU and Indian institutions, businesses and civil society. The aim is to jointly implement concrete projects, to promote access to and disseminate clean energy and climate friendly technologies and encourage research and development. An Energy Panel meets annually at senior officials' level and an energy security working group was launched in $2016^{10}$.

India, recognising the importance of fusion energy research in its long-term energy security, participates (with the EU, US, China, Russia, Japan and South Korea) in the international ITER fusion project. ITER is a pioneering project to build and operate an experimental facility to demonstrate the scientific viability of fusion as a future sustainable energy source. Bilaterally the EU and India cooperate under a Euratom Cooperation Agreement on Fusion Energy Research, focussing on projects (20 are ongoing) supporting the success of ITER and the future construction of a fusion electricity demonstration facility (DEMO) ${ }^{11}$.

ITER ("The Way" in Latin) is one of the most ambitious energy projects in the world today. In southern France, 35 nations are collaborating to build the world's largest tokamak, a magnetic fusion device that has been designed to prove the feasibility of fusion as a large-scale and carbon-free source of energy based on the same principle that powers our Sun and stars. The experimental campaign that will be carried out at ITER is crucial to advancing fusion science and preparing the way for the fusion power plants of tomorrow. ITER will be the first fusion device to produce net energy. ITER will be the first fusion device to maintain fusion for long periods of time. And ITER will be the first fusion device to test the integrated technologies, materials, and physics regimes necessary for the commercial production of fusion-based electricity ${ }^{12}$.

\footnotetext{
${ }^{9}$ European Union External Action (2018).

${ }^{10}$ Working groups on various energy sectors are active, including on renewable and energy efficiency. Energy cooperation is thus ongoing on a broad range of energy issues, like smart grids, energy efficiency, offshore wind and solar infrastructure, and research and innovation. India was a key player in achieving a global climate agreement in Paris in December 2015.

${ }^{11}$ See www.iter.org.

${ }^{12}$ European Union External Action (2018).
} 
Regarding environment and water, the 2016 Summit launched an India-EU Water Partnership, which was followed by a Memorandum of Understanding. The EU and India also cooperate closely on the Indian Clean Ganga initiative and deal with other water-related challenges in coordinated manner ${ }^{13}$.

The EU has provided longstanding support to Indian cities to develop plans for sustainable development, transport, industry, water and waste management, and more recently established city-to-city cooperation between European and Indian cities such as Mumbai, Pune and Chandigarh in a first phase and twelve more cities involved in the current phase. The EU is also providing support to Indian cities to join the Global Covenant of Mayors on climate and clean energy. This cooperation is being formalised in an India-EU Partnership for Smart and Sustainable urbanisation, which will support the Indian 'Smart cities' and 'AMRUT' initiatives and will involve EU Member States for policy cooperation, business solutions and joint research \& innovation ${ }^{14}$.

The EU supports sectoral cooperation through an ever-increasing number of loans of the European Investment Bank (EIB), which on 31 March 2017 opened a regional office in New Delhi ${ }^{15}$. EIB loans support, for example, urban development projects (Lucknow and Bangalore Metro) and clean energy projects (renewable energy - solar power plants $)^{16}$.

\footnotetext{
${ }^{13}$ The EU works in a 'joined-up' approach, involving Member States, water authorities, business and NGO's. Discussions also take place in a Joint Working Group on Environment and an India-EU Environment Forum, along with business, academia and civil society. The dialogue focuses increasingly on global environmental issues including the transition to a green economy as well as emerging issues such as air quality. European Union External Action (2018).

${ }^{14}$ European Union External Action (2018).

${ }^{15}{ }^{15}$ The significant new European Investment Bank support signed today will strengthen expansion of clean energy generation across India. I welcome the continued cooperation between IREDA and the European Investment Bank that builds the clear success of new renewable energy and energy efficiency investment over the last four years," said R.K. Singh, Minister of State responsible for New and Renewable Energy. Agreements for the new loan for renewable energy investment was signed in New Delhi earlier today by Kuljit Singh Popli, Chairman and Managing Director of IREDA and Dr. Werner Hoyer, President of the European Investment Bank, in the presence of R.K. Singh, Minister of State responsible for New and Renewable Energy. "India is the world's third largest electricity consumer. The expansion of solar power generation alongside cutting energy use through energy efficiency measures is crucial to supporting sustainable economic development and reducing carbon emissions. The strengthened partnership between IREDA and the European Investment Bank reflects the joint commitment of India and the European Union to implement the Paris climate agreement. Investment in new solar energy and wind power schemes will improve access to clean energy for millions of Indians and create many new jobs. I am pleased that this flagship initiative could be highlighted to world leaders attending the International Solar Alliance summit here in New Delhi and showcased as a model to tackle energy challenges around the world," said Werner Hoyer, President of the European Investment Bank. European Investment Bank (2018). ${ }^{16}$ Ibid.
} 


\section{Research and Innovation}

India and the EU enjoy strong cooperation in the areas of research and innovation ${ }^{17}$. Both the EU and India are also looking at ways to enhance the innovation partnership by creating, amongst others, network events where startups from India and Europe can meet. An Implementing Arrangement (IA) between the EC and the Indian Science and Engineering Research Board (SERB) was signed allowing for short term cooperation between SERB grantees and ERC teams in Europe ${ }^{18}$.

\section{Digital India and Digital Single Market}

India and the EU aim to link the 'Digital Single Market' with the 'Digital India'. Regular dialogue on economic and regulatory matters is held in the Joint ICT Working Group and ICT Business Dialogue. Cooperation covers ICT market access issues, standardisation, Internet governance and research and innovation. A Partnership Instrument project supports cooperation on ICT standardisation on crucial topics of mutual interest (5G, machine-to-machine communications/ Intelligent Transport Systems, software defined and virtualised networks, and security), and a new "Start-up Europe India Network" initiative was launched in 2016. Further, an India-EU Cyber Security Dialogue has been set up that focusses on exchange of best practice on addressing cybercrime and strengthening cyber security and resilience, as well as an open cyber space. Dialogue with Indian partners on cyberspace is being further strengthened through the ongoing Partnership Instrument project on Cyber Diplomacy ${ }^{19}$.

\section{Biotechnology}

India and the EU hold regular dialogues at the Joint Working Group on Pharmaceuticals, Biotechnology and Medical Devices, covering economic and

\footnotetext{
${ }^{17}$ Regarding academic collaboration in particular, the EU is India's leading partner in terms of joint publications. Following the conclusion of the EU-India Science \& Technology Cooperation Agreement in 2001 (renewed in 2015 until 2020), India became a very active participant in the EC Framework Programmes for Research and Innovation. Participation in research and innovation funding programme 'Horizon 2020' (2014-2020) benefits from a cofunding mechanism agreed with the Indian Department of Science and Technology (DST), the Department of Biotechnology (DBT) in 2016 and most recently with Ministry of Earth Sciences (MoES) in 2018. Individual Indian researchers can receive grants from the European Research Council (ERC) or the Marie Skłodowska-Curie Actions (MSCA). At the India-EU Joint Steering Committee (June 2017, Brussels) and confirmed at the EU-India Summit in October 2017, it was agreed to upscale the collaborative research through joint calls. For example, see European Union (2017).

${ }^{18}$ European Union External Action (2018).

${ }^{19}$ European Union External Action (2018).
} 
regulatory matters. It must be stressed that India and the EU are very important partners in these areas ${ }^{20}$.

\section{Free Competition}

There is scope and interest on both the EU and Indian sides to strengthen cooperation on competition policy, in particular following the signature, in the margins of a visit of former European Commission Vice-President Almunia, of the India-EU Memorandum of Understanding on Competition Policy (November 2013, New Delhi) ${ }^{21}$.

On 21 November 2013, the European Commission signed a Memorandum of Understanding ('MoU') with the Competition Commission of India. A copy has just been published on the European Commission's website. The aim of the MoU is to further strengthen cooperation between the two parties in the area of antitrust enforcement. This MoU forms part of a wider and ever-increasing web of international agreements between antitrust authorities. India already has in place a MoU with the US Department of Justice (DoJ) and the Federal Trade Commission (FTC). The EU has concluded bilateral cooperation agreements/ MoUs on antitrust matters with an extensive list of countries, including China, US, Canada, Japan, India, South Korea, and Switzerland. Key provisions of the MoU are as follows: Exchange of information. Both parties acknowledge that it will be in "their mutual interest" to exchange non-confidential information with regard to competition policy, operational issues, multilateral competition initiatives (such as interaction with the ICN and OECD), competition advocacy, and technical cooperation activities. Coordination of enforcement activities. The MoU states that:

"Should the Sides pursue enforcement activities concerning the same or related cases they will endeavour to coordinate their enforcement activities, where this is possible".

\section{Mutual Assistance}

There are a number of provisions which deal with the possibility to request the other party to take enforcement action in its jurisdiction. These are as follows:

\footnotetext{
${ }^{20}$ Around $30 \%$ of active pharmaceutical ingredients sold in the EU are manufactured in India, while $75 \%$ of India's total demand for medical devices is currently met by imports, with nearly $30 \%$ of it being supplied by the EU alone. Strengthening cooperation contributes to patients' safety, addresses non-tariff trade barriers, and facilitates access of innovative EU industry to the growing Indian market. European Union External Action (2018).

${ }^{21}$ Cooperation between the EU and India on competition policy is being further strengthened through the ongoing Partnership Instrument on Competition Cooperation. See also Lovells (2013) and also Stamelos (2012).
} 
"6. If one of the Sides believes that anti-competitive actions carried out on the territory of the other Side adversely affect competition on the territory of the first Side, it may request that the other Side initiates appropriate enforcement activities as per their applicable competition law.

7. The requested Side will consider the possibility of initiating enforcement activities or expanding on-going enforcement activities with respect to the anti-competitive actions, identified by the requesting Side, in accordance with the requirements of its legislation and will inform the other Side about the results of such consideration.

8. Nothing in this Memorandum of Understanding will limit the discretion of the requested Side to decide whether to undertake enforcement activities with respect to the anti-competitive actions identified in the request, or will preclude the requesting Side from withdrawing its request."

\section{Avoidance of Conflicts}

The MoU provides a mechanism to avoid conflicts if one authority's enforcement activity may affect the other in its own enforcement activity. It is too early to tell how the key clauses of the MoU will be applied in practice and whether it will be a "game changer". However, the MoU certainly signals a clear intent for increased cooperation on antitrust matters between the EU and India. $^{22}$

\section{Migration and Mobility}

India and the EU strengthened cooperation on migration and mobility through the endorsement, at the 2016 Summit of the India-EU Common Agenda on Migration and Mobility (CAMM). An India-EU High Level Dialogue on Migration and Mobility was held on 4 April $2017^{23}$.

Each year, there are almost fifty thousand Indian students in over four thousand universities across Europe. Since the opening of the Erasmus programmes on higher education to third countries, India has been its largest beneficiary, with more than five thousand Indian students having received European scholarships to study in Europe. In the last 3 years alone, since Erasmus mundus transformed into Erasmus+, about one thousand five hundred students

\footnotetext{
${ }^{22}$ Lovells (2013).

${ }^{23}$ The CAMM addresses four priority areas in a balanced manner: better organised regular migration and the fostering of well-managed mobility; prevention of irregular migration and trafficking in human beings; maximising the development impact of migration and mobility; and the promotion of international protection. The four priority areas of CAMM are being jointly addressed through a 3-year project on EU-India Cooperation and Dialogue on Migration and Mobility, supported under the Partnership Instrument. The CAMM, as a framework for cooperation, is the start of a longer-term process which will lead to deeper cooperation and solid mutual engagement on migration, a key global policy area. European Union External Action (2018).
} 
have received full scholarships, one hundred twenty Indian universities have been involved in active exchange programmes, and around a hundred in joint master programmes or capacity-building projects. Nine eminent Indian professors are now teaching EU studies under the Jean Monnet programme ${ }^{24}$.

India's development cooperation with the EU has a successful track record, spanning several decades. Major focus areas include education, health, water and sanitation. Following India's developmental progress, since 2014 we are progressively moving beyond a traditional assistance-type agenda towards a partnership approach, including blending initiatives combining grants with loans from international financial institutions to leverage additional funding for specific development needs. In addition, the EU supports institutional capacity-building in key strategic areas such as renewable energies, trade and environment. India remains eligible for EU thematic and regional co-operation aid programmes. Over one hundred fifty million Euros worth of projects are currently ongoing in India. At the 2017 EU-India Summit, leaders decided to strengthen cooperation on the implementation of the 2030 Agenda $^{25}$.

The strategic partnership between the EU and India is being furthermore supported by the EU's Partnership Instrument which already plays an important role in providing new avenues for continued India-EU engagement. Projects are ongoing to support the implementation of the India-EU Agenda for Action-2020 in areas such as ICT, energy, water, climate change, urban development, resource efficiency, migration and mobility, competition cooperation, cyber security, and public diplomacy, among others ${ }^{26}$.

\section{Conclusion}

If Brexit may weaken the EU in the coming years, India and the EU shall get the benefits out of their strategic partnership which both parties shall continuously pursue to develop and deepen. Such partnership may not be limited to trade and investment, but it should cover all economic, social and humanistic sectors. After all, the ultimate goal shall be the joint prosperity of all citizens of India and the EU in our common future. In that regard, rules, regulations, laws and further bilateral agreements, treaties, joint sessions and summits shall facilitate a holistic partnership of the EU and India.

\footnotetext{
${ }^{24}$ European Union External Action (2018).

${ }^{25}$ European Union External Action (2018).

${ }^{26}$ European Union External Action (2018).
} 


\section{References}

European Investment Bank. (2018). More than one million Indian households to benefit from EIB backed clean energy, Press Release, 10 March, 2018-064-EN.

European Union. (2017). EU-India Water Cooperation on Research and Innovation, Joint Call for Proposals, www.dst.gov.in/sites/default/files/India-EU\%20Water\%20Call \%202017-18\%20Call\%20Text\%20\%26amp\%3B\%20Guidelines.pdf.

European Union External Action. (2018). EU-India relations, Fact sheet, https://eeas.Eu ropa.eu/headquarters/headquarters-homepage/4010/eu-india-relations-fact-sheet_en, 20 June, Brussels.

Lavelle, M. (2018). Trump's Science Adviser Pick: Extreme Weather Expert with Climate Credentials. https://insideclimatenews.org/news/01082018/kelvin-droegemeier-tru mp-picks-white-house-science-adviser-climate-change-extreme-weather, 1 August 2018.

Lovells, H. (2013). Cooperation between the EU and India on antitrust matters, Lexology, December 2013.

NDTV (2018). US praises India for its Significant Counter-Terrorism Actions, www.ndtv.com/india-news/us-praises-india-for-its-significant-counter-terrorismactions-1919482, 20 September 2018.

Rattani, V. (2017). Can India-EU strategic partnership focus on climate change, clean energy? www.downtoearth.org.in/news/climate-change/can-india-eu-strategic-part nership-focus-on-climate-change-clean-energy--58819, 6 October.

Stamelos, H. (2012). The US-EU Agreement on the application of the antitrust laws, The interrelation of the extraterritoriality of the antitrust laws of the parties (in Greek), Nomiki Bibliothiki, Athens.

Zahid, F. (2017). The Future of Terrorism in India, 50 Foreign Analysis, Centre Francais de Recherche sur le Renseignement, www.cf2r.org/foreign/the-future-of-terrorismin-india/, December 2017

\section{Appendix A - India-EC Cooperation Agreement 1993/1994}

Cooperation Agreement between the European Community and the Republic of India on partnership and development, OJ L 223, 27.8.1994. https://eur-lex.europa.eu/legalcontent/EN/TXT/PDF/?uri=CELEX:21994A0827(01)\&from=EN, at 24-34.

\section{Appendix B - India-EU Strategic Partnership 2004}

Communication from the Commission to the Council, the European Parliament and the European Economic and Social Committee - An EU-India Strategic Partnership \{SEC(2004) 768, COM/2004/0430final $\}$. https://eur-lex.europa.eu/legal-content/EN/ TXT/PDF/?uri=CELEX:52004DC0430\&from=EN 
